\title{
Long-term coastal openness variation and its impact on sediment grain-size distribution: a case study from the Baltic Sea
}

\author{
Wenxin Ning ${ }^{1, *}$, Jing Tang ${ }^{2,3, *}$, and Helena L. Filipsson ${ }^{1}$ \\ ${ }^{1}$ Department of Geology, Lund University, Sölvegatan 12, 22362 Lund, Sweden \\ ${ }^{2}$ Terrestrial Ecology Section, Department of Biology, University of Copenhagen, \\ 2100 Copenhagen $\varnothing$, Denmark \\ ${ }^{3}$ Center for Permafrost (CENPERM), University of Copenhagen, 1350 Copenhagen K, Denmark \\ *These authors contributed equally to this work. \\ Correspondence to: Wenxin Ning (wenxin.ning@geol.lu.se)
}

Received: 12 April 2016 - Published in Earth Surf. Dynam. Discuss.: 21 April 2016

Revised: 12 July 2016 - Accepted: 21 September 2016 - Published: 11 October 2016

\begin{abstract}
We analysed the long-term variations in grain-size distribution in sediments from Gåsfjärden, a fjordlike inlet in the southwestern Baltic Sea, and explored potential drivers of the recorded changes in the sediment grain-size data. Over the last 5.4 thousand years (ky) in the study region, the relative sea level decreased $17 \mathrm{~m}$, which was caused by isostatic land uplift. As a consequence, Gåsfjärden was transformed from an open coastal setting to a semi-closed inlet surrounded by numerous small islands on the seaward side. To quantitatively estimate the morphological changes in Gåsfjärden over the investigated time period and to further link the changes to the grain-size distribution data, a digital elevation model (DEM)-based openness index was calculated. The largest values of the openness indices were found between 5.4 and $4.4 \mathrm{cal} \mathrm{ka} \mathrm{BP}$, which indicates relatively high bottom water energy. During the same period, the highest sand content $(\sim 0.4 \%)$ and silt / clay ratio $(\sim 0.3)$ in the sediment sequence were also recorded. After $4.4 \mathrm{cal} \mathrm{kaBP}$, the average sand content was halved to $\sim 0.2 \%$ and the silt / clay ratio showed a significant decreasing trend over the last $4 \mathrm{ky}$. These changes were found to be associated with the gradual embayment of Gåsfjärden, as represented by the openness indices. The silt / clay ratios exhibited a delayed and relatively slower change compared with the sand content, which indicates different grain-size sediment responses to the changes in hydrodynamic energy. Our DEM-based coastal openness indices have proved to be a useful tool for interpreting the temporal dynamics of sedimentary grain size.
\end{abstract}

1

Sedimentary grain-size distribution provides important information regarding depositional conditions and has been widely analysed in both modern samples and sediment cores (e.g. Tanner, 1992; Yang et al., 2008; Virtasalo et al., 2014). Grain-size distribution is generally governed by sediment inputs and hydrodynamic energy conditions. The higher the energy conditions, the larger proportion of coarse grains (Dearing, 1997; Jönsson et al., 2005). Water depth, wind direction and strength, basin morphometry, and man-made constructions such as dams could influence bottom water hydrody- namics and may lead to different characteristics in grain-size distributions. The Baltic Sea is connected with the North Sea through the narrow Danish Straits. Although tidal activity can strongly influence grain-size distribution in coastal regions, as shown by Zhang et al. (2002), the tidal amplitude recorded in the Baltic Sea is only a few centimetres (Ekman and Stigebrandt, 1990) and therefore its impact on sediment grain size is not considered in this region. Instead, wind conditions and coastal morphometry are considered to be the most important factors that influence the sedimentary grainsize distribution in the Baltic Sea coastal zone (Lehmann 
et al., 2002; Jönsson et al., 2005; Al-Hamdani and Reker, 2007).

During the Holocene, the Baltic Sea has experienced several stages modulated by global sea-level changes as well as isostatic land uplift (Björck, 1995; Andrén et al., 2011). As the late Weichselian ice sheet retreated, land uplift during the deglaciation and the Holocene resulted in shoreline displacements in the coastal zones of the Baltic Sea. A maximum of $60 \mathrm{~m}$ decline in relative sea level (RSL) has been recorded over the last 6 thousand years (ky) (Påsse and Andersson, 2005), leading to basin isolations and long-term changes in the coastal morphometry (Eronen et al., 2001). These changes in the coastal morphometry variations may potentially be linked with variations in grain-size distributions, as shown from a coastal inlet in the southwest of Baltic Sea (Ning et al., 2016a).

To examine the impact of coastal morphometry changes on grain-size distribution in a long-term perspective, quantifying the morphological changes, e.g. water depth and crosssection areas, could be useful. Achieving this quantification is data-demanding, since it requires (1) high-resolution bathymetry data, (2) the correct cross-section area and (3) sedimentation rates. However, all these data are difficult to obtain and make the quantification difficult. Alternatively, through using digital elevation maps, Lindgren (2011) proposed a geographical information system (GIS)-based wave fetch index, named filter factor, to estimate coastal morphometry. The result of the quantified coastal morphometry was found to be significantly correlated with bottom water dynamics (Persson and Håkanson, 1995) and deepwater turnover time (Persson and Håkanson, 1996). There are also other GIS-based indices that exist for describing coastal openness and wave exposure (Ekebom et al., 2003; Tolvanen and Suominen, 2005), and these GIS-based methods have also been applied to investigate sediments grain-size distributions from lakes and coastal zones (Håkanson, 1977; Lindgren and Karlsson, 2011). However, these aforementioned indices are restricted to depicting the modern coastal morphometry and have not yet been employed in a palaeoenvironmental context.

In this study, we proposed an openness index using digital elevation model (DEM) data, and this approach could provide an opportunity to estimate long-term coastal morphometry variations for the Holocene. Furthermore, we innovatively used the coastal openness index for grain-size data interpretations. The aim of the study is to (1) present a method for quantifying openness changes in coastal region that experienced large relative sea level as well as shoreline changes and to (2) link the estimated openness index with the long-term sediment grain-size distribution.

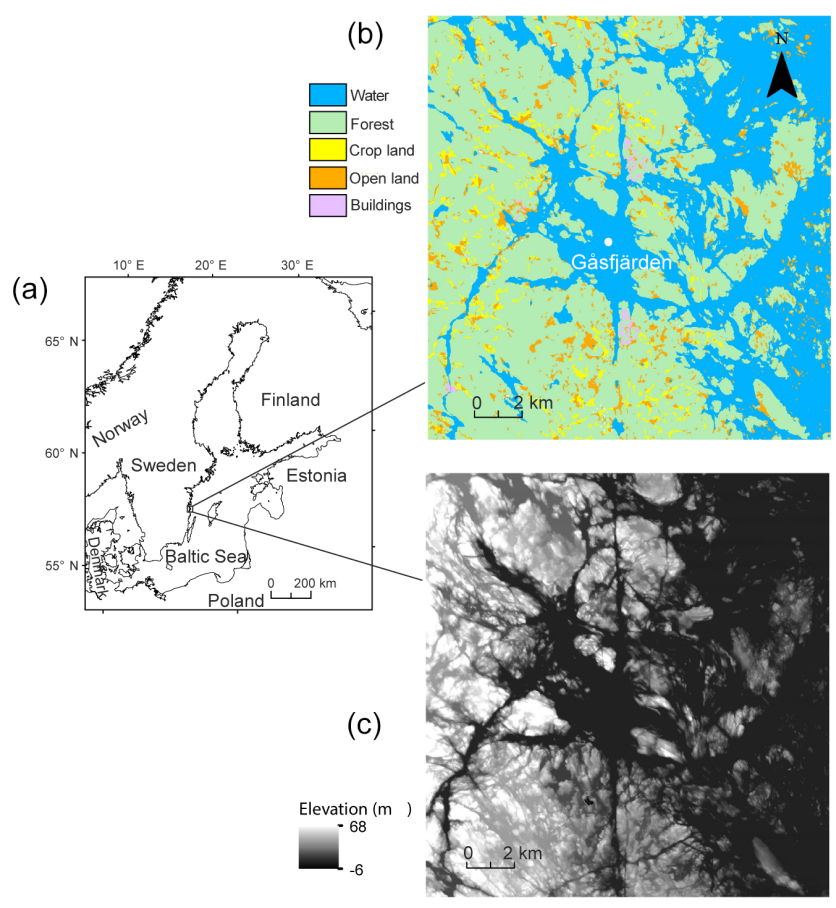

Figure 1. (a) Overview of the Baltic Sea region and the location of Gåsfjärden, (b) the coring site (white circle) and land use map, and (c) the digital elevation model of the study region.

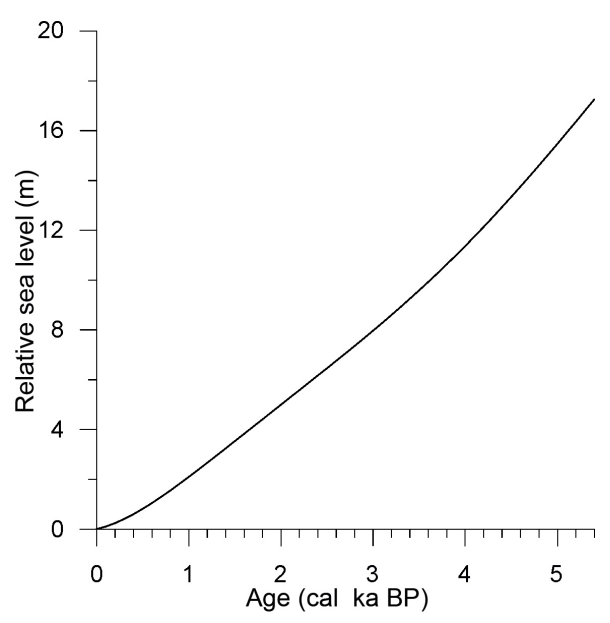

Figure 2. Changes of relative sea level in the study area over the last $5.4 \mathrm{ky}$ based on the empirical model by Påsse and Andersson (2005).

\section{Materials and methods}

\subsection{Study area and digital elevation model}

Gåsfjärden is a semi-enclosed fjord-like inlet located on the southeast Swedish Baltic Sea coast (Fig. 1a). It has a restricted water exchange with the open Baltic Sea through a narrow and shallow strait ( $\sim 500 \mathrm{~m}$ wide, $<20 \mathrm{~m}$ deep) in the east, which hinders sediment transport between the inlet and 

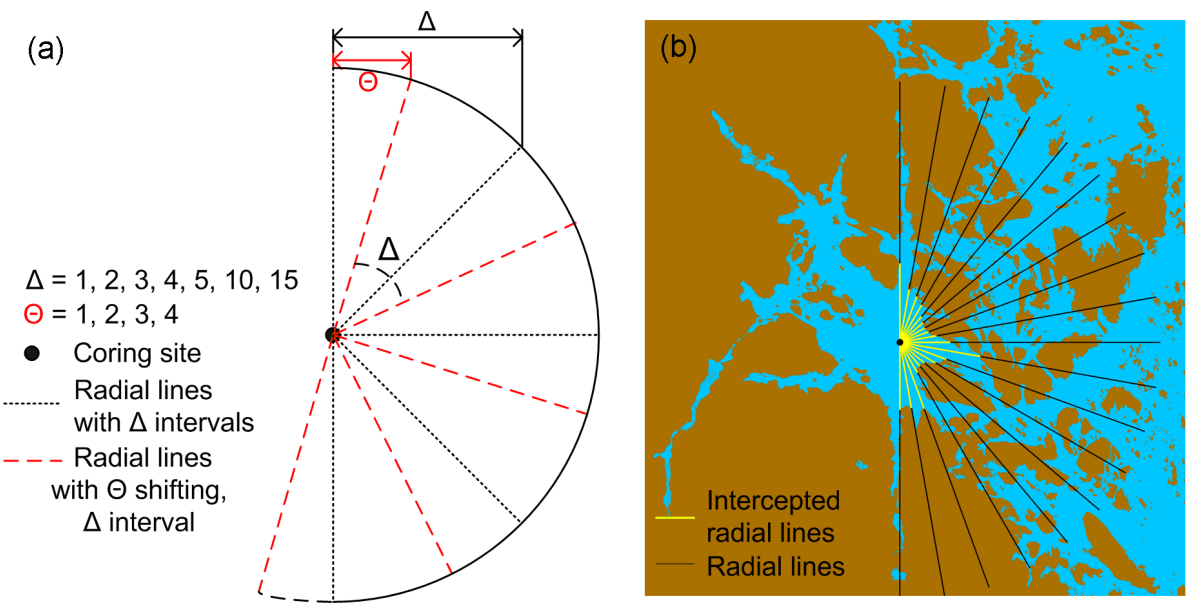

Figure 3. (a) Illustration of the $180^{\circ}$ radiating lines, the intervals $(\Delta)$, and the shifting angles $(\Theta)$. (b) Black and yellow lines represent the $8 \mathrm{~km}$ long radial lines and the intercepted lines for openness index calculation.

open waters. The surface area of Gåsfjärden is $22 \mathrm{~km}^{2}$ and the mean and maximum water depths are 10 and $51 \mathrm{~m}$, respectively. The RSL has decreased by $17 \mathrm{~m}$ in the region over the last $5.4 \mathrm{ky}$ as a result of isostatic land uplift (Fig. 2) and the present land uplift rate is around $1.5 \mathrm{~mm} \mathrm{yr}^{-1}$ (Påsse and Andersson, 2005). The catchment of Gåsfjärden is characterised by very thin soils $(<1 \mathrm{~m})$ and exposed pre-Cambrian bedrock. Arable land is sparsely distributed in the lowlands and vegetation mainly consists of coniferous forest (Fig. 1b). Small-scale human activities existed in the region as early as $2 \mathrm{ky}$ ago, although substantial expansion has occurred since the 1700s (Karlsson et al., 2015; Ning et al., 2016a). In the shallow waters of the inlet, sandy patches can be found in addition to the rocky coast. The sediment accumulating in the inlet most likely originates from the terrestrial environment through erosion, and from land-run and river transport, instead of from the open Baltic Sea. Sediment accumulation rate over the last 1000 years is generally less than $1.5 \mathrm{~mm} \mathrm{yr}^{-1}$ in the deep basin (Ning et al., 2016a).

The light detection and ranging (lidar)-based DEM data of the study region (Fig. 1c) were obtained from the Swedish mapping agency, Lantmäteriet (http://www.lantmateriet.se/). The horizontal and vertical resolutions of the DEMs are approximately 2 and $0.1 \mathrm{~m}$, respectively. The data are in the Swedish national coordinate system (SWEREF99 TM).

\subsection{Chronology and grain-size analysis}

Sediment cores were collected at station VG31 $\left(57^{\circ} 34^{\prime} 21.3^{\prime \prime} \mathrm{N}, 16^{\circ} 34^{\prime} 58.4^{\prime \prime} \mathrm{E}\right)$ in August 2011 on the $\mathrm{R} / \mathrm{V}$ Ocean Surveyor. A $6 \mathrm{~m}$ sediment sequence was obtained and the age-depth model was established through a combination of ${ }^{210} \mathrm{~Pb},{ }^{137} \mathrm{Cs}$ and AMS- ${ }^{14} \mathrm{C}$ dating methods (Ning et al., 2016a). For the grain-size analysis, organic carbon, calcium carbonate, and biogenic silica were removed from the sediment samples using procedures by Van Hengs- tum et al. (2007). To obtain enough minerogenic material, a mixed sediment sample of about $13 \mathrm{~g}$, with core sections of a maximum of $7 \mathrm{~cm}$ (covering $\sim 60$ years), was used. The sand particles $(>63 \mu \mathrm{m})$ were sieved, dried and weighed. The mass fraction of sand was calculated by dividing the dried sand weight by the original dry sample weight before any chemical treatment. The mass fractions of clay $(<2 \mu \mathrm{m})$ and silt $(2-63 \mu \mathrm{m})$ from particles less than $63 \mu \mathrm{m}$ were obtained with a Micromeritics SediGraph III particle size analyser at the Department of Geology, Lund University, Sweden.

\subsection{Openness index}

The calculation of the openness index (Fig. 3) has been modified on the basis of the method described by Lindgren (2011) and the fetch-length method of Ekebom et al. (2003). The following steps for estimating openness index variations were taken in ArcGIS 10.3:

1. The coring site was identified in the DEM.

2. Using the coring site as a starting point, two sets of $180^{\circ}$ circles of radiating lines were created. One set of radial lines was towards the east (seaward) and the other was towards the west (landward), with an interval of $\Delta$ degree (generated by the Python scripts in Supplement S1). The length of the radiating lines was set as $8 \mathrm{~km}$ and the interval $\Delta$ was set as $1-5,10$ and $15^{\circ}$. The radial lines of $8 \mathrm{~km}$ were used as they can reach offshore open water. The radial lines with a $5^{\circ}$ interval but with different shifting angles $\theta\left(1-4^{\circ}\right)$ were also created (Fig. 3a).

3. The RSL changes with a 100-year interval were applied to the present-day DEM. For every 100 years, a new DEM was generated and the RSL changes were based on the age-RSL relationship in Fig. 2. 

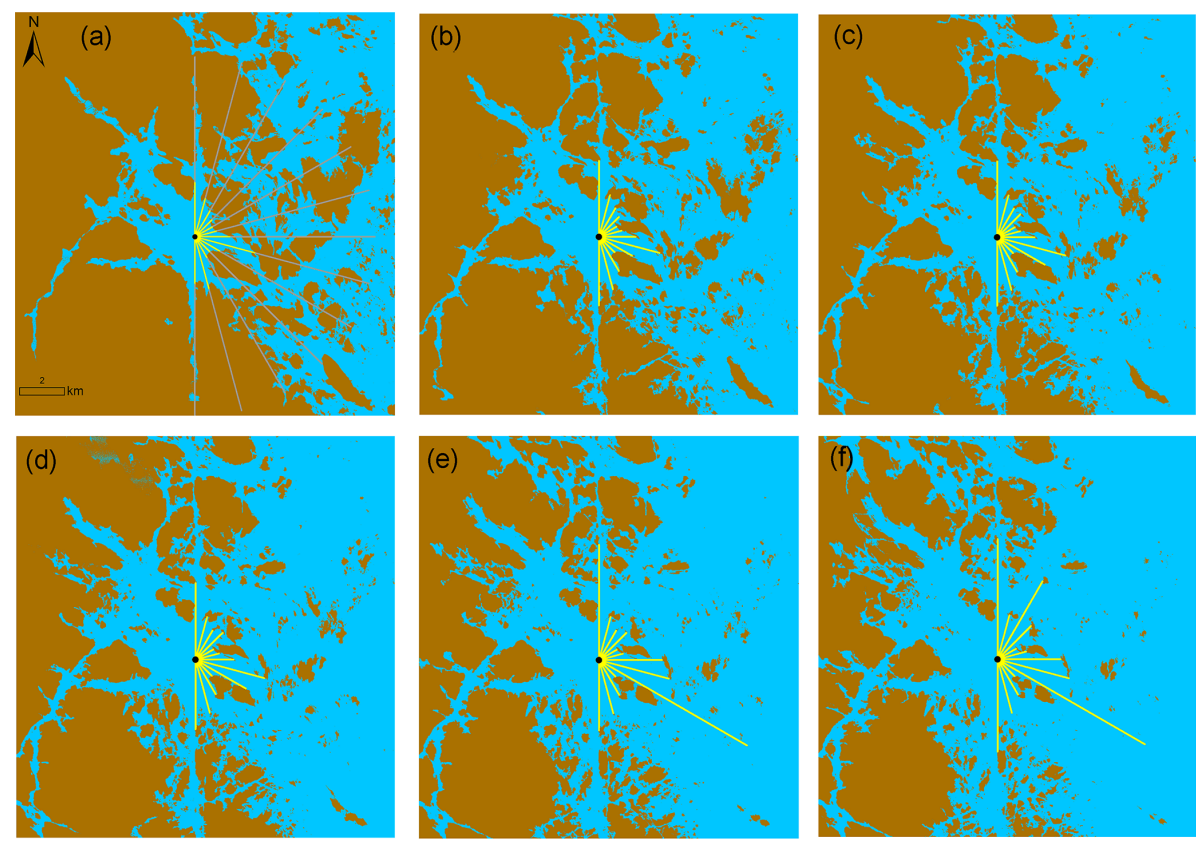

Figure 4. Illustrations showing the variations in seaward radial lines intercepted with land over the last $5.4 \mathrm{ky}$ : (a) $0.1 \mathrm{cal} \mathrm{kaBP}$, (b) $2.5 \mathrm{cal} \mathrm{ka} \mathrm{BP,} \mathrm{(c)} 3.5 \mathrm{cal} \mathrm{ka} \mathrm{BP,} \mathrm{(d)} 4 \mathrm{cal} \mathrm{ka} \mathrm{BP,} \mathrm{(e)} 4.5 \mathrm{cal} \mathrm{ka} \mathrm{BP}$, and (f) $5.4 \mathrm{cal} \mathrm{ka} \mathrm{BP}$.

4. For every 100 years, the grid cells in the generated DEM were classified as sea or land based on the elevation.

5. The raster DEMs were converted to land and sea polygons for vector calculation in ArcGIS, and the radiating lines generated in step 2 were divided into smaller segments when the lines were intersected by the land polygons.

6. The lines originating from the coring site and that came into contact with the land were selected (see Figs. 4 and 5). The seaward and landward openness indices were calculated as the average length of the selected radiating lines.

\section{Results and discussion}

\subsection{Estimated openness indices under different scenarios}

The openness indices with different intervals have been estimated in order to determine an optimal interval for applying this index for the study area. The seaward and landward openness indices, calculated with 15 and $10^{\circ}$ intervals, exhibited relatively large year-to-year deviations compared with the indices using the relatively smaller degree intervals (Fig. 6). The calculated landward and seaward indices using the $15^{\circ}$ interval are at maximum 7 and $20 \%$ larger than the $1^{\circ}$ interval scenario. Only minor differences (maximum $5 \%$ ) were observed between the openness indices calculated using 1,2 and $3^{\circ}$ intervals. Generally, the larger degree of intervals, such as 5,10 and $15^{\circ}$, resulted in fewer radial lines; as a consequence, the weights of a few very long or short radial lines on the average length will be relatively larger compared with the estimation using smaller intervals. Therefore, the associated uncertainties in the estimated openness index will be larger when using radial lines with larger intervals. The high frequency of radial lines, e.g. using a $1^{\circ}$ interval, ensures a higher possibility for capturing the details of the coastal openness variability. Furthermore, potential effects of shifting angles (angle between the north and the nearest radial line) were tested, and Fig. 7 shows the cases for the $5^{\circ}$ interval of radial lines with shifting angles of 0 to $4^{\circ}$. The results demonstrate that using different shifting angles can cause substantial differences in the estimated openness indices when the radial intervals are relatively large. However, if the interval is set as $1^{\circ}$, changing the shifting angle from 0 to $4^{\circ}$ would result in openness indices with very small differences considering the relative changes in the positions of all radial lines. Therefore, using a low degree interval such as $1^{\circ}$ for calculating the openness indices is preferred and should be recommended for other similar studies, although the computing time would be longer than higher degree intervals. The landward and seaward openness indices were differentiated even though they both reflect morphological changes in the inlet over the last $5.4 \mathrm{ky}$. The seaward openness index more accurately reflected the embayment process in comparison with the landward openness index, as the most distinct changes of the inlet was from the sill in the east. The landward openness index, reflecting offshore distance, could also 

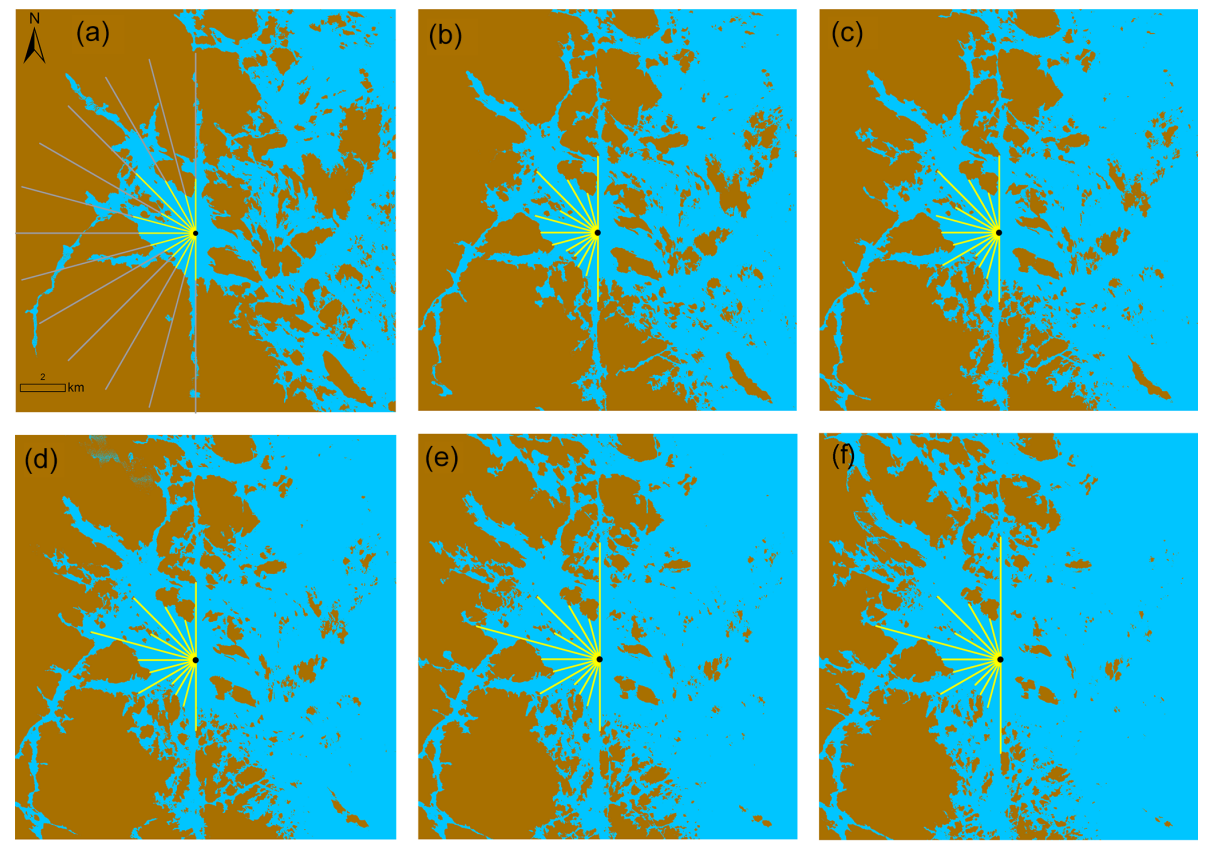

Figure 5. Illustrations showing the variations in landward radial lines intercepted with land over the last $5.4 \mathrm{ky}$ : (a) $0.1 \mathrm{cal} \mathrm{ka} \mathrm{BP}$, (b) $2.5 \mathrm{cal} \mathrm{ka} \mathrm{BP,} \mathrm{(c)} 3.5 \mathrm{cal} \mathrm{ka} \mathrm{BP,} \mathrm{(d)} 4 \mathrm{cal} \mathrm{ka} \mathrm{BP,} \mathrm{(e)} 4.5 \mathrm{cal} \mathrm{ka} \mathrm{BP}$, and (f) $5.4 \mathrm{cal} \mathrm{ka} \mathrm{BP}$.
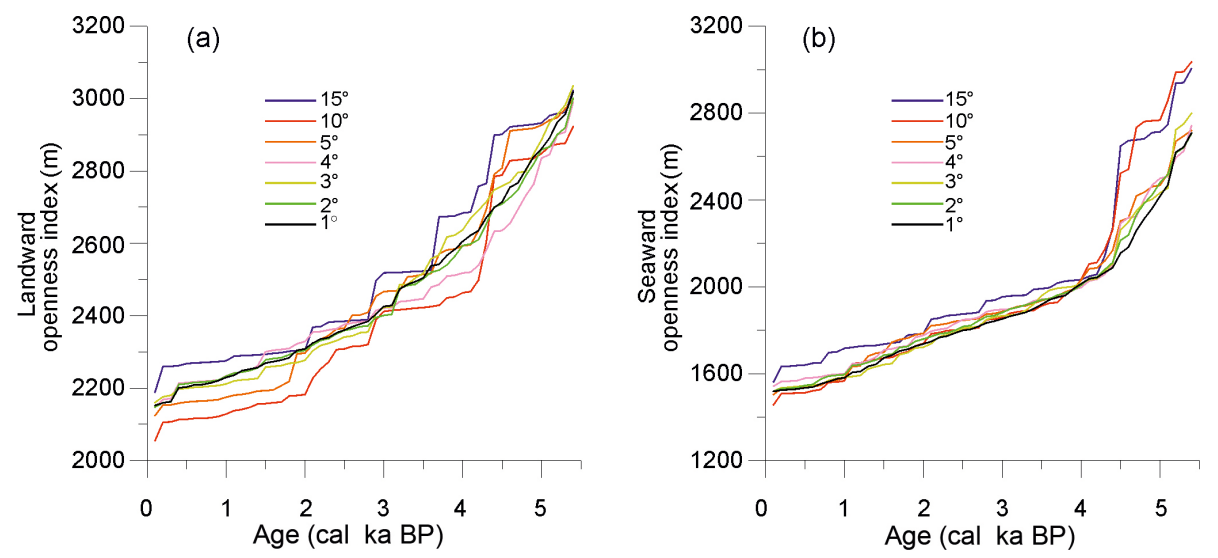

Figure 6. Calculated landward (a) and seaward (b) openness indices of Gåsfjärden over the last 5.4 ky, using $1-5,10$ and $15^{\circ}$ intervals.

be important for considering sedimentary grain size. Seaward and landward openness indices have demonstrated a continuous decline over the last $5.4 \mathrm{ky}$ (Fig. 6), caused by isostatic land uplift and the embayment process. The decreasing rate of the seaward openness index was more pronounced during 5.4-4.4 cal ka BP than the period of 4.4-0.1 cal ka BP. In contrast, the decline in the landward openness index was relatively smoother and no drastic transition was recorded $\sim 4.4 \mathrm{cal} \mathrm{ka} \mathrm{BP}$.

\subsection{Implications for sediment grain-size distributions}

The openness indices calculated with a $1^{\circ}$ interval and $0^{\circ}$ shifting angle were plotted along with the grain-size data
Table 1. Correlation $\left(r^{2}, p<0.01\right)$ matrix for the grain-size data and the calculated openness indices.

\begin{tabular}{lcc}
\hline Index & Sand & Silt/clay \\
\hline Landward openness & 0.48 & 0.65 \\
Seaward openness & 0.47 & 0.56 \\
\hline
\end{tabular}

(Fig. 8). The correlations $\left(r^{2}\right)$ between the openness indices and grain-size data range between 0.47 and 0.65 ( $p<$ 0.01 ) (Table 1). The significant correlation suggested that the change in coastal openness was an important factor influencing the sedimentary grain-size distribution. Both the sea- 

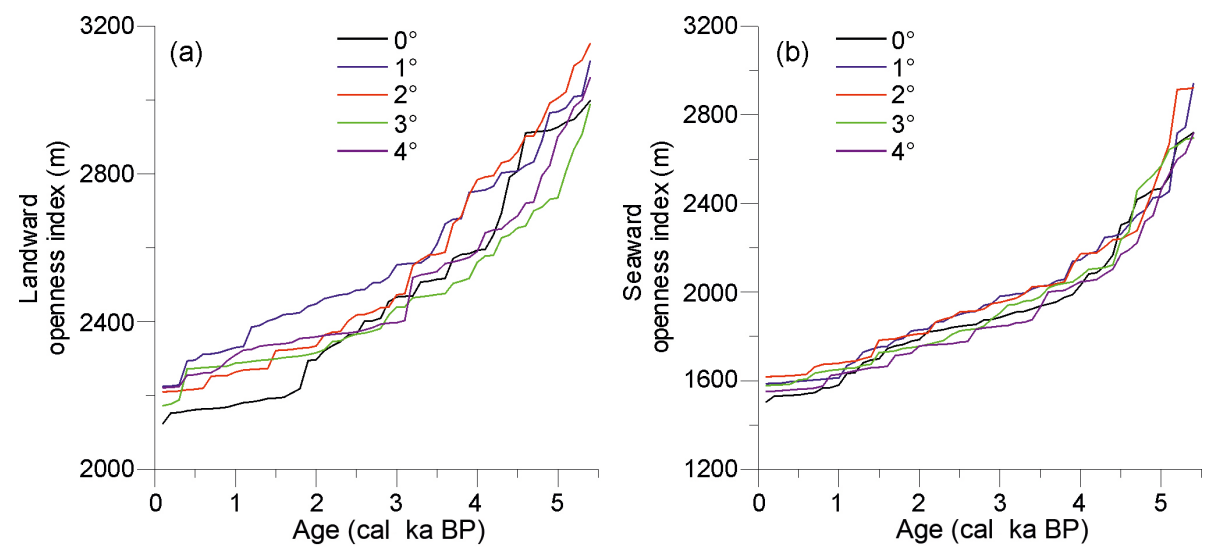

Figure 7. Calculated landward (a) and seaward (b) openness indices with $5^{\circ}$ interval and $1-4^{\circ}$ shift starting angles.

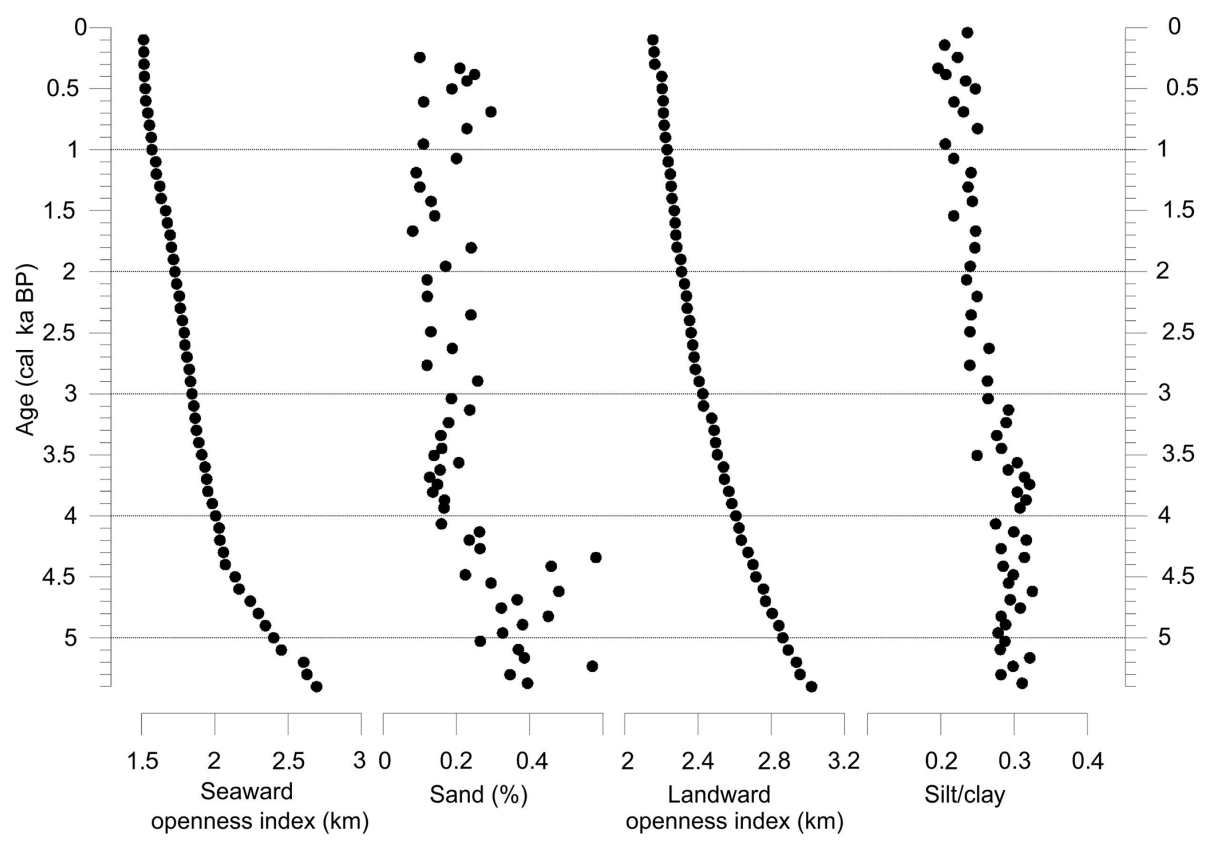

Figure 8. The calculated openness indices using $1^{\circ}$ interval and $0^{\circ}$ shifting and the measured grain size from the sediment.

ward openness index and sand content had the highest values between 5.4 and $4.4 \mathrm{cal} \mathrm{ka} \mathrm{BP}$, and there is a synchronous large decline in seaward openness and sand content around $4.4 \mathrm{cal} \mathrm{kaBP}$ (Fig. 8). This further indicates a connection between the depositional environment and coastal openness variations. The maximum sand content at the coring site was only $\sim 0.4 \%$, suggesting a relatively low bottom water velocity compared with open Baltic Sea waters (Jönsson et al., 2005). Generally, in coastal zones, the closer to the shore, the more coarse-grained sediments can be deposited. However, the sediments in Gåsfjärden became more and more fine-grained as the coring site became shallower and closer to the shore (closer to present time, see Figs. 5 and 8), which was a result of less exposure and an increasingly protected location. At present, the seafloor outside Gåsfjärden is charac- terised by sandy sediments, whereas gyttja clay is deposited in the sheltered Gåsfjärden (Al-Hamdani and Reker, 2007). The modern grain-size difference between the areas inside and outside Gåsfjärden is linked to the different hydrodynamic statuses. The relatively higher sand content during 5.4-4.4 cal ka BP may also be associated with the increased sand transport when Gåsfjärden had a relatively larger crosssectional area. Based on an analysis of 201 sites along the Swedish coast characterised by complex bathymetry, Lindgren and Karlsson (2011) estimated that the mean critical depth separating the depositional areas from the erosion and transport areas is located at $19 \mathrm{~m}$. At present, our coring site has a water depth of $31 \mathrm{~m}$. The relatively deeper water depth (sediment dominated by transport, instead of erosion) to- 
gether with sheltered condition resulted in the low sand content.

Erosion from the surrounding islands since $5.4 \mathrm{ka}$ has most likely occurred, but it has been rather limited as these islands are mostly rocky with little soil cover. It may, however, result in a flux of relatively coarser grains to the coring site during uplifting of the land. As the uplift process has shown to be linear (see Fig. 2), we might expect to see a rather linear change in the grain-size data if the uplifting of the land had played the dominant role. However, the sand content and silt / clay ratios exhibit strong year-to-year variations, which indicates other factors than land uplifting could also participate in influencing grain-size distribution. For instance, coarse grains, such as sand, can also be transported to the coring site through storm events and intense wave action, sea ice or drifting seaweed. However, their impacts are not explicitly included in the openness indices. Furthermore, the recorded large variability in the sand content within the last millennium may be linked with catchment disturbance from human activities (Karlsson et al., 2015; Ning et al., 2016a).

The silt/clay ratios also reflected bottom water energy, with higher values indicating higher energy conditions. The silt / clay ratio was $\sim 0.3$ between 5.4 and $4.0 \mathrm{cal} \mathrm{kaBP}$ and exhibited a continuous decline from $4.0 \mathrm{cal} \mathrm{ka} \mathrm{BP}$. The different pattern between the silt/clay and sand content, particularly during the period when Gåsfjärden was relatively open, between 5.4 and $4.0 \mathrm{cal} \mathrm{ka} \mathrm{BP}$, suggested that different grain-size sediments respond differently to the changes in hydrodynamic conditions in this region. The decrease in sand content from 5.4 to $4.4 \mathrm{cal} \mathrm{ka}$ BP indicates a decline in bottom water velocity. However, the bottom water velocity was probably still high enough to maintain the silt / clay ratios, as silt and clay might have responded similarly to the changes in hydrodynamics. Different grain-size classes that respond differently to hydrodynamic changes have also been reported in two coastal sites in Italy (Molinaroli et al., 2009), where positive correlations between current velocities and silt (8$63 \mu \mathrm{m})$ and fine sand $(63-105 \mu \mathrm{m})$ fractions were found in two lagoons. The changes in landward openness, which reflect the offshore distance, seem to follow the silt/clay ratios $\left(r^{2}=0.65\right)$. In our data, the silt / clay ratios exhibited a significant decreasing trend ( $p<0.01$, Mann-Kendall test) between 4.0 and $0.1 \mathrm{cal} \mathrm{kaBP}$, which indicates a long-term impact of decreased coastal openness on the grain-size distributions.

\section{Conclusions}

Our DEM-based calculations of coastal openness indices have shown to be a useful tool when interpreting longterm sedimentary grain-size data. A relatively high RSL was linked with large coastal openness and higher hydrodynamic energy, which in turn was well reflected in the seaward openness index. The higher values of both sand con- tent and the seaward openness index were recorded in the early part of the record, indicating that coastal morphology (presented by openness index) strongly influenced sand distribution. The differences in temporal dynamics of sand content and silt / clay ratios indicate that different grain-size sediments responds differently to the changes in hydrodynamic energy. The significant decline in silt / clay ratios between 4 and $0.1 \mathrm{ka}$ demonstrated that the long-term impacts of coastal openness on the finer grain-size sediment distributions. Our DEM-based openness index can be easily applied to other coastal settings that have experienced large sea-level changes over time. The index could also be further used in predicting future dynamics by combing information about sea-level changes in a warmer future.

\section{Data availability}

All data used in this manuscript are available at Pangaea (doi:10.1594/PANGAEA.865211; Ning et al., 2016b).

\section{The Supplement related to this article is available online at doi:10.5194/esurf-4-773-2016-supplement.}

Acknowledgements. $\mathrm{Z}$. Wu is thanked for help with data analysis. The project was funded by FORMAS Strong Research Environment: Managing Multiple Stressors in the Baltic Sea (217-2010-126). We thank the captain and crew of R/V Ocean Surveyor for help during sampling. We thank N. V. Putten and $\AA$. Wallin for guidance during grain-size analysis. We also acknowledge funding from the Crafoord Foundation and the Royal Physiographic Society in Lund. J. Tang was financed by the Villum Foundation (VKR022589) and the Danish National Research Foundation (CENPERM DNRF100). We thank Evan Goldstein and the anonymous reviewer for their helpful comments on the manuscript.

Edited by: O. Duran Vinent

Reviewed by: E. Goldstein and one anonymous referee

\section{References}

Al-Hamdani, Z. and Reker, J.: Towards marine landscapes in the Baltic Sea, BALANCE Interim Report No. 10, available at: http: //balance-eu.org/, 2007.

Andrén, T., Björck, S., Andrén, E., Conley, D., Zillén, L., and Anjar, J.: The Development of the Baltic Sea Basin During the Last 130 ka, in: The Baltic Sea Basin, edited by: Harff, J., Björck, S., and Hoth, P., Central and Eastern European Development Studies (CEEDES), Springer, Berlin Heidelberg, 75-97, 2011.

Björck, S.: A review of the history of the Baltic Sea, 13.0-8.0 ka BP, Quat. Int., 27, 19-40, doi:10.1016/1040-6182(94)00057-C, 1995. 
Dearing, J. A.: Sedimentary indicators of lake-level changes in the humid temperate zone: a critical review, J. Paleolimnol., 18, 114, 10.1023/A:1007916210820, 1997.

Ekebom, J., Laihonen, P., and Suominen, T.: A GIS-based step-wise procedure for assessing physical exposure in fragmented archipelagos, Estuar. Coast Shelf Sci., 57, 887-898, doi:10.1016/S0272-7714(02)00419-5, 2003.

Ekman, M. and Stigebrandt, A.: Secular change of the seasonal variation in sea level and of the pole tide in the Baltic Sea, J. Geophys. Res.-Oceans, 95, 5379-5383, doi:10.1029/JC095iC04p05379, 1990.

Eronen, M., Gluckert, G., Hatakka, L., Plassche, O. V. D., Plicht, J. V. D., and Rantala, P.: Rates of Holocene isostatic uplift and relative sea-level lowering of the Baltic in SW Finland based on studies of isolation contacts, Boreas, 30, 17-30, doi:10.1111/j.15023885.2001.tb00985.x, 2001.

Håkanson, L.: The influence of wind, fetch, and water depth on the distribution of sediments in Lake Vänern, Sweden, Can. J. Earth Sci., 14, 397-412, doi:10.1139/e77-040, 1977.

Jönsson, A., Danielsson, ̊̊., and Rahm, L.: Bottom type distribution based on wave friction velocity in the Baltic Sea, Cont. Shelf Res., 25, 419-435, doi:10.1016/j.csr.2004.09.011, 2005.

Karlsson, J., Segerström, U., Berg, A., Mattielli, N., and Bindler, R.: Tracing modern environmental conditions to their roots in early mining, metallurgy, and settlement in Gladhammar, southeast Sweden: Vegetation and pollution history outside the traditional Bergslagen mining region, The Holocene, 25, 944-955, doi:10.1177/0959683615574586, 2015.

Lehmann, A., Krauss, W., and Hinrichsen, H. H.: Effects of remote and local atmospheric forcing on circulation and upwelling in the Baltic Sea, Tellus A, 54, 299-316, doi:10.1034/j.16000870.2002.00289.x, 2002.

Lindgren, D.: Determining openness and energy filtering in coastal areas using geographic information systems, Estuar. Coast Shelf Sci., 91, 177-186, doi:10.1016/j.ecss.2010.10.018, 2011.

Lindgren, D. and Karlsson, M.: Assessment of the relationship between coastal morphometry, bottom dynamic conditions and the critical depth, Air Soil Water Res., 4, 31-56, 2011.

Molinaroli, E., Guerzoni, S., De Falco, G., Sarretta, A., Cucco, A., Como, S., Simeone, S., Perilli, A., and Magni, P.: Relationships between hydrodynamic parameters and grain size in two contrasting transitional environments: The Lagoons of Venice and Cabras, Italy, Sediment. Geol., 219, 196-207, doi:10.1016/j.sedgeo.2009.05.013, 2009.
Ning, W., Ghosh, A., Jilbert, T., Slomp, C. P., Khan, M., Nyberg, J., Conley, D. J., and Filipsson, H. L.: Evolving coastal character of a Baltic Sea inlet during the Holocene shoreline regression: impact on coastal zone hypoxia, J. Paleolimnol., 55, 319-338, doi:10.1007/s10933-016-9882-6, 2016.

Ning, W., Tang, J., and Filipsson, H. L.: Grain size distribution and sea level changes in Gåsfjärden fjord, PANGAEA, doi:10.1594/PANGAEA.865211, 2016b.

Påsse, T. and Andersson, L.: Shore-level displacement in Fennoscandia calculated from empirical data, GFF, 127, 253268, doi:10.1080/11035890501274253, 2005.

Persson, J. and Håkanson, L.: Prediction of bottom dynamic conditions in coastal waters, Mar. Freshwater Res., 46, 359-371, 1995.

Persson, J. and Håkanson, L.: A simple empirical model to predict deepwater turnover time in coastal waters, Can. J. Fish Aquat. Sci., 53, 1236-1245, doi:10.1139/f96-048, 1996.

Tanner, W. F.: Late Holocene sea-level changes from grain-size data: evidence from the Gulf of Mexico, The Holocene, 2, 249254, doi:10.1177/095968369200200306, 1992.

Tolvanen, H. and Suominen, T.: Quantification of openness and wave activity in archipelago environments, Estuar. Coast Shelf Sci., 64, 436-446, doi:10.1016/j.ecss.2005.03.001, 2005.

Van Hengstum, P. J., Reinhardt, E. G., Boyce, J. I., and Clark, C.: Changing sedimentation patterns due to historical land-use change in Frenchman's Bay, Pickering, Canada: evidence from high-resolution textural analysis, J. Paleolimnol., 37, 603-618, doi:10.1007/s10933-006-9057-y, 2007.

Virtasalo, J. J., Ryabchuk, D., Kotilainen, A. T., Zhamoida, V., Grigoriev, A., Sivkov, V., and Dorokhova, E.: Middle Holocene to present sedimentary environment in the easternmost Gulf of Finland (Baltic Sea) and the birth of the Neva River, Mar. Geol., 350, 84-96, doi:10.1016/j.margeo.2014.02.003, 2014.

Yang, S. L., Li, H., Ysebaert, T., Bouma, T. J., Zhang, W. X., Wang, Y. Y., Li, P., Li, M., and Ding, P. X.: Spatial and temporal variations in sediment grain size in tidal wetlands, Yangtze Delta: On the role of physical and biotic controls, Estuar. Coast Shelf Sci., 77, 657-671, doi:10.1016/j.ecss.2007.10.024, 2008.

Zhang, C., Wang, L., Li, G., Dong, S., Yang, J., and Wang, X.: Grain size effect on multi-element concentrations in sediments from the intertidal flats of Bohai Bay, China, Appl. Geochem., 17, 59-68, doi:10.1016/S0883-2927(01)00079-8, 2002. 